\title{
Schlesneria paludicola gen. nov., sp. nov., the first acidophilic member of the order Planctomycetales, from Sphagnum-dominated boreal wetlands
}

Correspondence Svetlana N. Dedysh dedysh@mail.ru

\author{
Irina S. Kulichevskaya, ${ }^{1}$ Anastasia O. Ivanova, ${ }^{1}$ Svetlana E. Belova, ${ }^{1}$ \\ Olga I. Baulina, ${ }^{2}$ Paul L. E. Bodelier, ${ }^{3}$ W. Irene C. Rijpstra, ${ }^{4}$ \\ Jaap S. Sinninghe Damsté, ${ }^{4}$ George A. Zavarzin ${ }^{1}$ and Svetlana N. Dedysh ${ }^{1}$
${ }^{1}$ S. N. Winogradsky Institute of Microbiology, Russian Academy of Sciences, Prospect 60-letya Octyabrya 7/2, Moscow 117312, Russia \\ ${ }^{2}$ M. V. Lomonosov Moscow State University, Faculty of Biology Science, GSP-2, Leninskie Gory, \\ Moscow 119992, Russia \\ ${ }^{3}$ Netherlands Institute of Ecology, 3631 AC Nieuwersluis, The Netherlands \\ ${ }^{4}$ Royal Netherlands Institute for Sea Research, Department of Marine Biogeochemistry and \\ Toxicology, PO Box 59, 1790 AB Den Burg, The Netherlands
}

\begin{abstract}
Three strains of budding, ellipsoid-shaped and rosette-forming bacteria were isolated from acidic Sphagnum-dominated boreal wetlands of northern Russia and were designated strains MPL7 ${ }^{\top}$, MOB77 and SB2. The presence of crateriform pits and numerous fibrillar appendages on the cell surface and an unusual spur-like projection on one pole of the cell indicated a planctomycete morphotype. These isolates are moderately acidophilic, mesophilic organisms capable of growth at $\mathrm{pH}$ values between 4.2 and 7.5 (with an optimum at $\mathrm{pH}$ 5.0-6.2) and at temperatures between 4 and $32{ }^{\circ} \mathrm{C}$ (optimum $15-26{ }^{\circ} \mathrm{C}$ ). The major fatty acids are $\mathrm{C}_{16: 0}$ and $\mathrm{C}_{16: 1} \omega 7 \mathrm{c}$; the major quinone is MK-6. The $\mathrm{G}+\mathrm{C}$ content of the DNA is $54.4-56.5$ mol\%. Strains MPL7 ${ }^{\top}$, MOB77 and SB2 possess nearly identical 16S rRNA gene sequences and belong to the planctomycete lineage defined by the genus Planctomyces, being most closely related to Planctomyces limnophilus DSM $3776^{\top}$ (86.9-87.1\% sequence similarity). However, strain MPL7 ${ }^{\top}$ showed only $28 \%$ DNA-DNA hybridization with $P$. limnophilus DSM $3776^{\top}$. Compared with currently described members of the genus Planctomyces, the isolates from northern wetlands do not form long and distinctive stalks, have greater tolerance of acidic conditions and low temperatures, are more sensitive to $\mathrm{NaCl}$, lack pigmentation and degrade a wider range of biopolymers. The data therefore suggest that strains MPL7 ${ }^{\top}, \mathrm{MOB} 7$ and SB2 represent a novel genus and species, for which the name Schlesneria paludicola gen. nov., sp. nov., is proposed. Strain MPL7 ${ }^{\top}\left(=\right.$ ATCC BAA-1393 ${ }^{\top}=$ VKM B- $\left.2452^{\top}\right)$ is the type strain of Schlesneria paludicola.
\end{abstract}

The order Planctomycetales comprises a remarkable group of budding bacteria that possess highly distinctive cell morphology, peptidoglycan-less cell walls and a unique cell organization (König et al., 1984; Schlesner \& Stackebrandt, 1986; Staley et al., 1992; Fuerst, 1995, 2004, 2005; Ward et al., 2006). Originally described as freshwater organisms,

Abbreviations: FAME, fatty acid methyl ester; PLFA, phospholipid fatty acid.

The GenBank/EMBL/DDBJ accession number for the 16S rRNA gene sequence of strain MPL7 $7^{\top}$ is AM162407.

Additional electron micrographs and temperature and $\mathrm{pH}$ growth profiles are available as supplementary material with the online version of this paper. members of this order were later shown to be ubiquitous in a wide range of aquatic and terrestrial environments with diverse conditions. Despite the reported widespread distribution, the known ecophysiological types of planctomycetes are quite limited. With the only exception of moderately thermophilic Isosphaera pallida (Giovannoni et al., 1987), all taxonomically described planctomycetes are both mesophilic and neutrophilic.

Until recently, there has been only one report on the isolation of a planctomycete-like strain from an acidic environment, i.e. peat bog water ( $\mathrm{pH} 4.2)$ of the Kaltenhofer Moor near Kiel, Germany (Schlesner, 1994). This strain has not been described taxonomically, and no further information except a brief morphological 
characterization was given. We recently reported that planctomycetes represent one of the most numerous bacterial groups detectable by fluorescence in situ hybridization in acidic Sphagnum-dominated wetlands (Dedysh et al., 2006; Kulichevskaya et al., 2006; Ivanova \& Dedysh, 2006). We have also reported the isolation of a few peatinhabiting planctomycetes in pure culture (Dedysh et al., 2006; Kulichevskaya et al., 2006). One of these isolates, strain $\mathrm{MPL7}^{\mathrm{T}}$, belonged to a phylogenetic lineage defined by the genus Planctomyces (Dedysh et al., 2006). The $16 \mathrm{~S}$ rRNA gene sequence from isolate MPL7 $^{\mathrm{T}}$ showed $87 \%$ similarity to that of the type strain of Planctomyces limnophilus (Hirsch \& Müller, 1985), one of three cultured species of the genus Planctomyces. Later, we obtained two other isolates with similar morphology from Sphagnum peat. In this paper, we describe the characteristics and taxonomic position of these isolates from peat bogs.

Two strains, MPL7 ${ }^{\mathrm{T}}$ and SB2, were isolated from acidic peat soil ( $\mathrm{pH} 4.0)$ sampled at a depth of $10-20 \mathrm{~cm}$ (with a water table at approximately $15 \mathrm{~cm}$ depth) of the Sphagnum peat bog Bakchar, Tomsk region, western Siberia $\left(56^{\circ} 51^{\prime} \mathrm{N} 82^{\circ} 50^{\prime} \mathrm{E}\right)$. Another strain, MOB77, was obtained from a peat sample ( $\mathrm{pH} 4.2)$ collected from the upper $(0-10 \mathrm{~cm})$ oxic layer of the bog Obukhovskoe, Yaroslavl region, in European northern Russia $\left(58^{\circ} 14^{\prime} \mathrm{N}\right.$ $\left.38^{\circ} 12^{\prime} \mathrm{E}\right)$. The isolation procedure and the culture conditions used were described elsewhere (Dedysh et al., 2006; Kulichevskaya et al., 2006). The isolates were maintained on agar medium M31 (modification of medium 31 described by Staley et al., 1992) containing (g per litre distilled water unless indicated) $\mathrm{KH}_{2} \mathrm{PO}_{4}, 0.1$; Hutner's basal salts, $20 \mathrm{ml} ; \mathrm{N}$-acetylglucosamine, 1.0; ampicillin sodium salt, 0.2 ; peptone, 0.1 ; yeast extract, 0.1 ; agar-agar (Difco), 18. The medium was adjusted to pH 5.8. Planctomyces limnophilus DSM $3776^{\mathrm{T}}$ (Hirsch \& Müller, 1985) was used as a reference strain in our study. It was maintained on medium 621 recommended by the Deutsche Sammlung von Mikroorganismen und Zellkulturen (DSMZ, Braunschweig, Germany) for cultivation of this bacterium.

Morphological observations and cell-size measurements were made with a Zeiss Axioplan 2 microscope and Axiovision 4.2 software (Zeiss). For negative staining, cells were dried onto grids and treated with $1 \%(\mathrm{w} / \mathrm{v})$ phosphotungstic acid. For the preparation of ultrathin sections, cells from 10-day-old cultures were fixed in $2 \%$ $(\mathrm{w} / \mathrm{v})$ glutaraldehyde in $0.1 \mathrm{M}$ sodium cacodylate buffer $(\mathrm{pH}$ 6.8) for $0.5 \mathrm{~h}$ and then post-fixed in $1 \%(\mathrm{w} / \mathrm{v})$ osmium tetroxide in the same buffer for $4 \mathrm{~h}$, dehydrated through an ethanol series and embedded in araldite. Thin sections were cut on an LKB-8800 ultratome and stained with lead citrate (Reynolds, 1963). Negatively stained cells and thin sections were examined with JEOL transmission electron microscopes JEM-100B and JEM-1011. For scanning electron microscopy, bacteria were fixed in $2 \%$ $(\mathrm{w} / \mathrm{v})$ glutaraldehyde in liquid medium M31 without carbon sources for $0.5-1 \mathrm{~h}$ and in some cases post-fixed in $1 \%(\mathrm{w} / \mathrm{v})$ osmium tetroxide in the same medium for $4 \mathrm{~h}$. The samples were then dehydrated through an ethanol series, left in absolute acetone overnight, critical-pointdried (Dryer HCP-2), coated with Au-Pd alloy (IB-3 Ion Coater) and examined with a JEOL JSM-6380LA scanning electron microscope.

Physiological tests were performed in liquid medium M31. Growth of strains MPL7 ${ }^{\mathrm{T}}$, MOB77 and SB2 was monitored by nephelometry at $600 \mathrm{~nm}$ in an Eppendorf BioPhotometer for 7-14 days under a variety of conditions, including temperatures of $4-37{ }^{\circ} \mathrm{C}, \mathrm{pH} 3.8-8.0$ and $\mathrm{NaCl}$ concentrations of $0-3.0 \%(\mathrm{w} / \mathrm{v})$. Variations in the $\mathrm{pH}$ were achieved by mixing $0.1 \mathrm{M}$ solutions of $\mathrm{H}_{2} \mathrm{SO}_{4}$ and $\mathrm{KOH}$. Carbon source utilization was determined using mineral medium MM supplemented with respective carbon sources $(0.05 \%, \mathrm{w} / \mathrm{v})$. Medium $\mathrm{MM}$ contained (g per litre distilled water) $\mathrm{KH}_{2} \mathrm{PO}_{4}, 0.1 ;\left(\mathrm{NH}_{4}\right)_{2} \mathrm{SO}_{4}, 0.1 ; \mathrm{MgSO}_{4} .7 \mathrm{H}_{2} \mathrm{O}, 0.1$; and $1 \mathrm{ml}$ metal salt solution '44' (Staley et al., 1992), the $\mathrm{pH}$ being adjusted to 5.5. Cultivation was done in $100 \mathrm{ml}$ flasks containing $10 \mathrm{ml}$ medium. Cultures were incubated at $25{ }^{\circ} \mathrm{C}$ for $2-3$ weeks on a shaker. The capacity to degrade different biopolymers was examined by measuring the rate of $\mathrm{CO}_{2}$ production in tightly closed $120 \mathrm{ml}$ serum bottles containing $10 \mathrm{ml}$ liquid medium MM with $0.05 \%(\mathrm{w} / \mathrm{v})$ of the corresponding polymer substrate for 1 month at $20{ }^{\circ} \mathrm{C}$. Control incubations were run in parallel under the same conditions but without substrate. Oxidative and fermentative utilization of carbohydrates was determined as described for the Hugh-Leifson test (Gerhardt et al., 1981). Nitrogen sources were tested using liquid MM medium with $0.05 \%$ glucose in which $\left(\mathrm{NH}_{4}\right)_{2} \mathrm{SO}_{4}$ was replaced with one of the following compounds at a concentration of $0.05 \%(\mathrm{w} / \mathrm{v}): \mathrm{KNO}_{3}, \mathrm{KNO}_{2}$, urea or one of the amino acids listed in Table 1. Gelatin liquefaction was assessed using 'method 2' described by Gerhardt et al. (1981) but, instead of mercury chloride, we used hot saturated ammonium sulfate. Susceptibility to antibiotics was determined on M31 agar plates using discs (Oxoid) containing the following antibiotics: ampicillin $(10 \mu \mathrm{g})$, gentamicin $(10 \mu \mathrm{g})$, kanamycin $(30 \mu \mathrm{g})$, neomycin $(10 \mu \mathrm{g})$, novobiocin $(30 \mu \mathrm{g})$, streptomycin $(10 \mu \mathrm{g})$, chloramphenicol $(30 \mu \mathrm{g})$ and lincomycin $(10 \mu \mathrm{g})$.

For fatty acid, neutral lipid and quinone analyses, cells of the novel isolates were grown on liquid medium M31 and harvested in the late exponential growth phase. Lipids were extracted from freeze-dried cell material using a modified Bligh and Dyer extraction procedure (Boschker et al., 1998, 2001). For phospholipid fatty acid (PLFA) analysis, the extract was fractionated on silicic acid into different polarity classes by sequential elution with chloroform, acetone and methanol. The methanol fraction containing the PLFA was derivatized using mild-alkaline methanolysis to yield fatty acid methyl esters (FAME). FAME standards of $\mathrm{C}_{12: 0}$ and $\mathrm{C}_{19: 0}$ were used for calculating retention indices and for quantification. Identification of FAMEs was based on retention time data against known standards. FAME concentrations were determined using a GC-FID 
Table 1. Phenotypic characteristics of strains $\mathrm{MPL}^{\top}, \mathrm{MOB} 77$ and SB2 in comparison with P. limnophilus $\mathrm{DSM} 3776^{\top}$

All strains utilized glucose, $\mathrm{N}$-acetylglucosamine, cellobiose, maltose, sucrose and trehalose. All strains were capable of hydrolysing chondroitin sulfate, xylan and pullulan and of gelatin liquefaction. None of the strains utilized fructose, rhamnose, sorbose, ribose, glycerol, methanol, ethanol, glucuronic acid, acetate, benzoate, caproate, citrate, fumarate, glutarate, lactate, malate, pyruvate, succinate, propionate, mannitol, tartrate, alanine, arginine, asparagine, aspartate, cysteine, cystine, glutamine, glycine, histidine, isoleucine, leucine, lysine, methionine, norleucine, ornithine, phenylalanine, proline, serine, threonine, tryptophan, tyrosine or valine. None of the strains was capable of hydrolysing starch or chitin. None of the strains utilized nitrite or urea as a nitrogen source. $+(\mathrm{w})$, Weak growth $\left(\mathrm{OD}_{600}\right.$ does not exceed 0.2).

\begin{tabular}{|c|c|c|c|c|}
\hline Characteristic & P. limnophilus DSM $3776^{\mathrm{T}}$ & Strain MPL7 ${ }^{\mathrm{T}}$ & Strain MOB77 & Strain SB2 \\
\hline Pigmentation & Pink to red & Unpigmented & Unpigmented & Unpigmented \\
\hline $\mathrm{pH}$ range for growth & $6.2-8.0$ & $4.2-7.2$ & $4.2-7.5$ & $4.2-7.7$ \\
\hline $\mathrm{pH}$ optimum & $6.2-7.0$ & $5.0-6.2$ & $5.0-6.2$ & $5.0-6.2$ \\
\hline Temperature range $\left({ }^{\circ} \mathrm{C}\right)$ & $17-39$ & $4-32$ & $4-32$ & $4-32$ \\
\hline \multicolumn{5}{|l|}{ Carbon sources } \\
\hline Fucose & - & + & + & + \\
\hline Galactose & + & - & - & - \\
\hline Lactose & + & + & - & - \\
\hline Melibiose & + & + & - & - \\
\hline Raffinose & + & - & - & - \\
\hline Pectin & - & $+(\mathrm{w})$ & $+(\mathrm{w})$ & $+(\mathrm{w})$ \\
\hline Lichenan & + & - & - & - \\
\hline \multicolumn{5}{|l|}{ Nitrogen sources } \\
\hline Nitrate & - & + & + & + \\
\hline $\begin{array}{l}\text { Alanine, aspartate, glutamine, } \\
\text { threonine }\end{array}$ & - & + & + & + \\
\hline DNA G $+\mathrm{C}$ content $(\mathrm{mol} \%)$ & $53.2 \pm 0.6$ & $56.3 \pm 0.3$ & $56.5 \pm 0.3$ & $54.4 \pm 0.5$ \\
\hline
\end{tabular}

system (Thermo Finnigan TRACE GC) equipped with a polar capillary column (SGE, BPX-70; $50 \mathrm{~m} \times$ $0.32 \mathrm{~mm} \times 0.25 \mu \mathrm{m}$ ) using the following oven conditions: initial temperature $50{ }^{\circ} \mathrm{C}$ for $1 \mathrm{~min}$, increasing to $130{ }^{\circ} \mathrm{C}$ by $40{ }^{\circ} \mathrm{C} \min ^{-1}$ and then increasing to $230{ }^{\circ} \mathrm{C}$ by $3{ }^{\circ} \mathrm{C}$ $\min ^{-1}$. To determine the double bond position of monounsaturated PLFAs, dimethyldisulfide (DMDS) derivatization was performed as described by Nichols et al. (1986). For neutral lipid analysis, the procedures described by Sinninghe Damsté et al. (2004) were used. Isoprenoid quinones were extracted according to Collins (1985) and analysed using a tandem-type mass spectrometer LCQ ADVANTAGE MAX and a Finnigan Mat 8430 ionization mass spectrometer.

Genomic DNA from the novel strains was extracted as described by Marmur (1961). The G+C content of DNA was determined by means of thermal denaturation using a Unicam SP1800 spectrophotometer at a heating rate of $0.5^{\circ} \mathrm{C} \mathrm{min}^{-1}$ and calculated according to Owen et al. (1969). DNA-DNA hybridization of strain MPL7 ${ }^{\mathrm{T}}$ and $P$. limnophilus DSM $3776^{\mathrm{T}}$ was performed as described by De Ley et al. (1970). PCR-mediated amplification of the $16 \mathrm{~S}$ rRNA gene from positions 28 to 1491 (numbering according to the International Union of Biochemistry nomenclature for Escherichia coli 16S rRNA) was performed using primers of and $1492 \mathrm{r}$ and reaction conditions described by Weisburg et al. (1991). 16S rRNA gene amplicons were purified using QIAquick spin columns (Qiagen) and sequenced on an ABI Prism 377 DNA sequencer using BigDye terminator chemistry, as specified by the manufacturer (PE Applied Biosystems). Phylogenetic analysis was carried out using the ARB program package (Ludwig et al., 2004).

Raised, opaque, uncoloured, small $(1-2 \mathrm{~mm})$, circular colonies with an entire edge and a smooth surface developed on agar medium M31 after incubation for 2 weeks at $24{ }^{\circ} \mathrm{C}$. Four-week-old colonies were $2-3 \mathrm{~mm}$ in diameter. Mature cells of strains MPL7 ${ }^{\mathrm{T}}, \mathrm{MOB} 77$ and SB2 had an ellipsoid-like shape and were 1.3-2.1 $\mu \mathrm{m}$ long and $0.6-1.5 \mu \mathrm{m}$ wide, being slightly larger than cells of $P$. limnophilus DSM $3776^{\mathrm{T}}$ (Table 1). Cells occurred singly or in pairs or were arranged in rosettes (Fig. 1a), and reproduced by budding (Fig. 1b). The buds arose from the free cell pole of the mother cells. After separation, they displayed high motility due to the possession of subpolar flagella. In most cases, two flagella per cell were observed. 

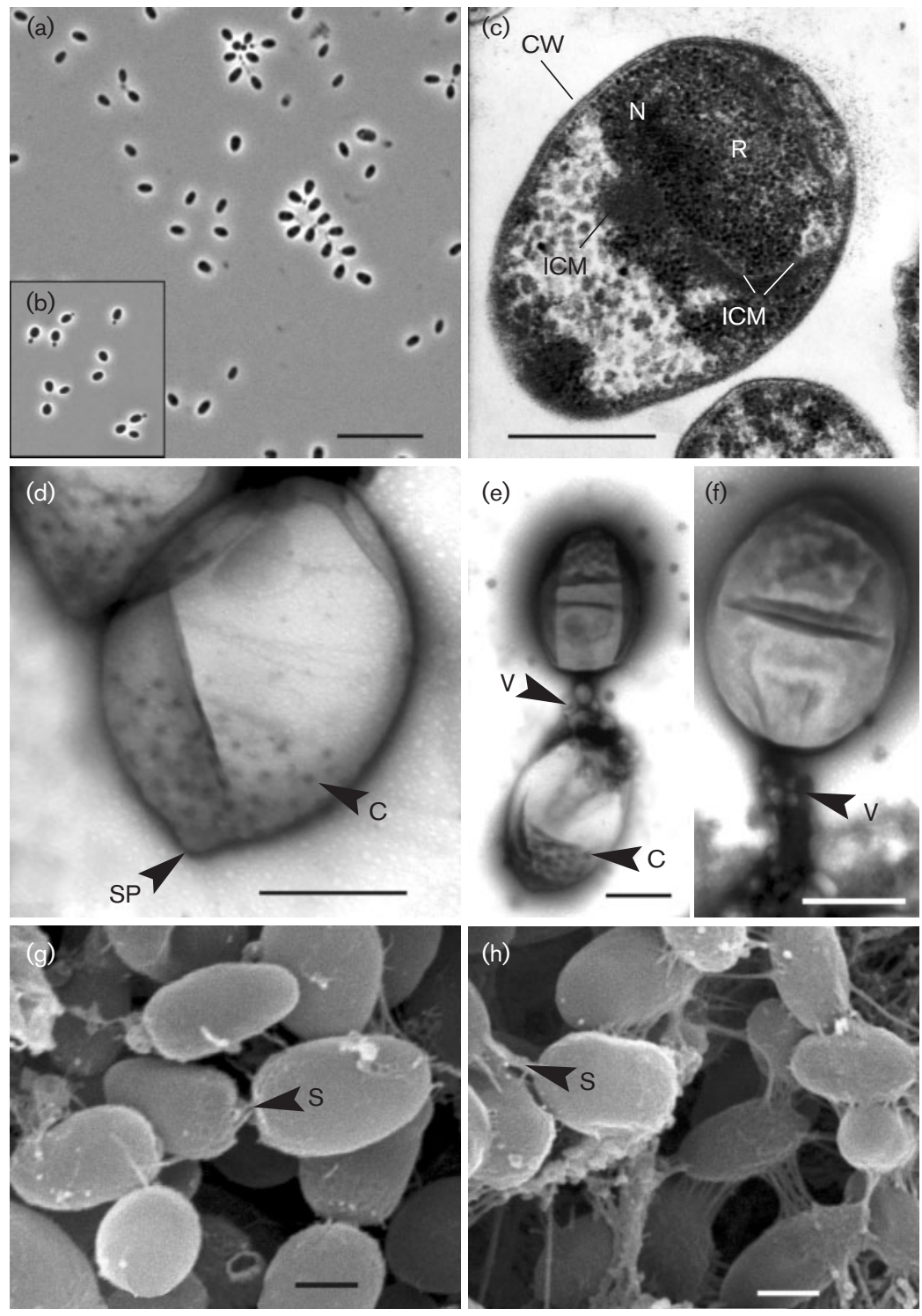

Fig. 1. $(a, b)$ Phase-contrast micrographs of mature (a) and budding (b) cells of strain $M P L 7^{\top}$. (c) Electron micrograph of an ultrathin section of a cell of strain MPL7 ${ }^{\top}$. CW, Cell wall; ICM, intracytoplasmic membrane; $\mathrm{N}$, nucleoid; R, riboplasm. (d-f) Electron micrographs of negatively stained cells displaying crateriform pits with polar distribution (d, e), a polar lemon-shaped cell projection (d) and vesicle-like bodies that cover the fibrillar material between the cells $(e, f) . \quad C$, Crateriform structures; V, vesicle-like bodies; $\mathrm{SP}$, spur-like projection. ( $g, \mathrm{~h})$ Scanning electron micrographs of cells of strain MPL7 ${ }^{\top}$ grown on SM agar medium (g) and in liquid medium MM with chondroitin sulfate (h). S, Short stalk-like structures. Bars, $10 \mu \mathrm{m}(\mathrm{a}$, bar also applies to b) and $0.5 \mu \mathrm{m}(\mathrm{c}-\mathrm{h})$.
Examination of thin sections revealed a characteristic type of cell organization in which a single membrane divides the cell into two major compartments (Fig. 1c). The nucleoid and most ribosomes were located in one of these compartments. This type of cell compartmentalization is characteristic of representatives of the genera Planctomyces and Pirellula (Lindsay et al., 2001; Fuerst, 2005; Ward et al., 2006). Examination of negatively stained cells using electron microscopy showed the presence of crateriform pits on the cell surface of the novel bacteria (Fig. 1d, e). These structures are highly characteristic of the planctomycete morphotype and displayed a polar distribution covering approximately one-third of the cell surface. We also observed an unusual spur-like projection on one pole of the cell, which gave the cell shape some similarity to a lemon (Fig. 1d). Similar spur-like projections have been observed before on cells of Planctomyces brasiliensis ATCC $49424^{\mathrm{T}}$ and Planctomyces sp. strain AGA/M18, isolated from the giant tiger prawn Penaeus monodon (Fuerst et al., 1997). Negative staining also revealed numerous, $4-8 \mathrm{~nm}$ thick, fimbria-like fibrillar structures (Supplementary Fig. S1A, available in IJSEM Online) as well as $10-15 \mathrm{~nm}$ thick fibrillar appendages (Supplementary Fig. S1B) on the cell surface of the novel strains. The fibrillar appendages developed more strongly when the cells were grown in liquid media with polymer growth substrates, such as chondroitin sulfate (Fig. 1h), and seem to play an important role in cell aggregation. Although formation of rosettes was commonly observed in cultures of the planctomycete-like isolates from peat bogs, we failed to discern the presence of stalks in these bacteria by observation with the phase-contrast microscope. When observed by the scanning electron microscope, the cells were seen to connect to each other by means of short stalklike structures (Fig. 1g, h). Some of these structures resembled the bundles of twisted fibrils (Fig. 1g). This 
fibrillar material between cells arranged in pairs as well as the inner parts of cell rosettes was often covered by vesiclelike, electron-transparent bodies, $20-100 \mathrm{~nm}$ in diameter, that were seen on negatively stained cell preparations (Fig. 1e, f). The nature of these vesicle-like bodies remains unclear.

Strains MPL7 ${ }^{\mathrm{T}}$, MOB77 and SB2 were facultatively aerobic chemoheterotrophs. They grew best under aerobic conditions on media with carbohydrates or $\mathrm{N}$-acetylglucosamine. However, similar to $P$. limnophilus (Hirsch \& Müller, 1985), the novel isolates were also capable of fermenting carbohydrates. This trait might be of special importance for bacteria that inhabit wetlands. It also coincides well with our recent finding that planctomycetes are present in anoxic layers of the peat bog profile (Ivanova \& Dedysh, 2006).

The list of carbon substrates tested in our experiments and the results are given in the species description and/or Table 1. In contrast to P. limnophilus DSM $3776^{\mathrm{T}}$, the novel isolates from Sphagnum peat did not assimilate galactose or raffinose, but assimilated fucose and salicin and were able to degrade a wider range of biopolymers. In addition to chondroitin sulfate, pullulan, gelatin and xylan, hydrolysed by $P$. limnophilus DSM $3776^{\mathrm{T}}$, strains MPL7 ${ }^{\mathrm{T}}$, MOB77 and SB2 were capable of hydrolysing fucoidan, laminarin, aesculin and pectin. All three novel isolates displayed catalase and cytochrome oxidase activities, but urease activity was absent. Dissimilatory nitrate reduction was positive. Growth factors were not required, but yeast extract increased the growth rate slightly. Ammonia, nitrate, $N$-acetylglucosamine, Bacto peptone, Bacto yeast extract, alanine, aspartate, glutamine and threonine were utilized as nitrogen sources. All three novel strains were resistant to ampicillin, streptomycin, chloramphenicol, lincomycin and novobiocin, but were sensitive to neomycin, kanamycin and gentamicin.

Strains MPL7 ${ }^{\mathrm{T}}$, MOB77 and SB2 grew in the $\mathrm{pH}$ range 4.27.5, with an optimum at $\mathrm{pH}$ 5.0-6.2 (Supplementary Fig. S2A). The temperature range for growth was 4$32{ }^{\circ} \mathrm{C}$, with an optimum at $15-26{ }^{\circ} \mathrm{C}$ (Supplementary Fig. $\mathrm{S} 2 \mathrm{~B})$. Growth was inhibited completely at $\mathrm{NaCl}$ concentrations above $0.5 \%(\mathrm{w} / \mathrm{v})$. Thus, compared with $P$. limnophilus DSM $3776^{\mathrm{T}}$, the isolates from northern wetlands had greater tolerance of acidic conditions and low temperatures and were more sensitive to $\mathrm{NaCl}$ (Table 1).

Similar to other described planctomycetes (Sittig \& Schlesner, 1993; Ward et al., 2006), our isolates contained menaquinone-6 (MK-6) as the predominant isoprenoid quinone. The cellular fatty acid compositions of strains MPL $^{\mathrm{T}}{ }^{2}$ MOB77 and SB2 displayed significant similarity to that of P. limnophilus DSM $3776^{\mathrm{T}}$ (Table 2). Similar to the latter species, the major components of the PLFA profile of the novel strains were $C_{16: 0}$ and $C_{16: 1} \omega 7 c$ fatty acids. However, compared with $P$. limnophilus DSM $3776^{\mathrm{T}}$, the PLFA profiles of our isolates had double the content of
Table 2. PLFA composition of the novel planctomycete strains from acidic peatlands in comparison with $P$. limnophilus DSM $3776^{\top}$

Values are percentages of total PLFAs (components making up $<0.1 \%$ of the total in all strains are not included). -, Not detected. Major PLFAs are shown in bold.

\begin{tabular}{|c|c|c|c|c|}
\hline Fatty acid & $\begin{array}{l}\text { Strain } \\
\text { MPL7 }^{T}\end{array}$ & $\begin{array}{c}\text { Strain } \\
\text { MOB77 }\end{array}$ & $\begin{array}{c}\text { Strain } \\
\text { SB2 }\end{array}$ & $\begin{array}{c}P . \\
\text { limnophilus } \\
{\text { DSM } 3776^{\mathrm{T}}}\end{array}$ \\
\hline $\mathrm{C}_{14: 0}$ & 0.16 & 0.19 & 0.17 & 0.17 \\
\hline ai $-C_{15: 0}$ & - & 0.12 & - & 0.11 \\
\hline $\mathrm{C}_{15: 0}$ & 0.23 & 0.14 & 0.26 & 0.89 \\
\hline $\mathrm{i}-\mathrm{C}_{16: 0}$ & 0.70 & 1.65 & 2.34 & 0.59 \\
\hline$C_{16: 0}$ & 43.46 & 45.95 & 49.64 & 45.72 \\
\hline 10-Methyl $C_{16: 0}$ & 0.39 & - & - & 0.12 \\
\hline $\mathrm{C}_{16: 1} \omega 5 t$ & - & 0.52 & - & - \\
\hline $\mathrm{C}_{16: 1} \omega 7 c$ & 46.77 & 42.6 & 40.27 & 17.78 \\
\hline ai $-C_{17: 0}$ & - & - & - & 0.10 \\
\hline $\mathrm{C}_{16: 1} \omega 5 c$ & 0.24 & - & - & - \\
\hline $\mathrm{C}_{17: 0}$ & 0.25 & 0.23 & 0.33 & 1.22 \\
\hline cyclo $C_{17: 0}$ & - & - & - & 2.10 \\
\hline $\mathrm{C}_{17: 1} \omega 6 c$ & - & 0.13 & 0.16 & 0.13 \\
\hline $\mathrm{C}_{18: 0}$ & 2.15 & 3.14 & 3.61 & 1.16 \\
\hline $\mathrm{C}_{18: 1} \omega 9 c$ & 1.30 & 0.62 & 0.54 & 22.21 \\
\hline $\mathrm{C}_{18: 1} \omega 7 c$ & 3.17 & 4.02 & 1.93 & 5.66 \\
\hline $\mathrm{C}_{19: 1} \omega 6$ & 0.65 & - & - & - \\
\hline ECL $19.165^{\star}$ & - & - & - & 0.35 \\
\hline cyclo $\mathrm{C}_{19: 0}$ & - & - & - & 0.16 \\
\hline$C_{20: 0}$ & - & 0.16 & 0.10 & 0.14 \\
\hline $\mathrm{C}_{20: 1} \omega 9$ & - & - & - & 1.12 \\
\hline
\end{tabular}

${ }^{\star}$ GC-MS and DMDS analyses did not give a definite identification. Tentative assignment is $\mathrm{C}_{19: 1} \omega 10$.

$\mathrm{C}_{16: 1} \omega 7 c$ and much lower contents of $\mathrm{C}_{18: 1} \omega 9 c$. A high content of $\mathrm{C}_{18: 1} \omega 9 \mathrm{c}$, which is not normally a major component in bacteria, was earlier regarded as a feature specific to members of Planctomyces and Pirellula (Kerger et al., 1988). Our study shows that not all planctomycetes possess significant amounts of this PLFA. The neutral lipid compositions of strains MPL7 ${ }^{\mathrm{T}}, \mathrm{MOB} 77$ and SB2 (Table 3) were highly similar and resembled that of $P$. limnophilus DSM $3776^{\mathrm{T}}$. All of these organisms contained a $n$-C 31 polyunsaturated alkene (9-10 double bonds) previously detected in Antarctic bacteria (Nichols et al., 1995) and a novel series of $\mathrm{C}_{24}-\mathrm{C}_{30} \beta,(\omega-1)$ diols. Compared with $P$. limnophilus DSM $3776^{\mathrm{T}}$, the novel strains contained much lower levels of $\mathrm{C}_{24}-\mathrm{C}_{26}$ alkan-1-ols, but higher levels of hop-22(29)-ene. The latter was previously detected in other planctomycetes (Sinninghe Damsté et al., 2004). This chemotaxonomic similarity supports the phylogenetic relationships outlined below.

Comparative sequence analysis of the 16S rRNA gene placed strains $\mathrm{MPL7}^{\mathrm{T}}$, MOB77 and SB2 into a phylogenetic cluster defined by members of the genus Planctomyces 
Table 3. Major neutral lipids of the novel planctomycete strains from acidic peatlands in comparison with $P$. limnophilus DSM $3776^{\top}$

Values are percentages of total neutral lipids.

\begin{tabular}{|c|c|c|c|c|}
\hline Compound & $\begin{array}{l}\text { Strain } \\
\text { MPL7 }^{T}\end{array}$ & $\begin{array}{c}\text { Strain } \\
\text { MOB77 }\end{array}$ & $\begin{array}{c}\text { Strain } \\
\text { SB2 }\end{array}$ & $\begin{array}{c}P . \\
\text { limnophilus } \\
\text { DSM } 3776^{\mathrm{T}}\end{array}$ \\
\hline$n-C_{31}$ polyene $^{*}$ & 25 & 23 & 26 & 27 \\
\hline$n$ - $\mathrm{C}_{24}$ alkan-1-ol & 0 & 0 & 1 & 23 \\
\hline$n$ - $\mathrm{C}_{26}$ alkan-1-ol & 1 & 1 & 1 & 8 \\
\hline$n-\mathrm{C}_{24}-2,23$-diol & 18 & 16 & 23 & 12 \\
\hline$n-\mathrm{C}_{26}-2,25$-diol & 42 & 42 & 41 & 29 \\
\hline$n-\mathrm{C}_{28}-2,27$-diol & 8 & 14 & 5 & 1 \\
\hline$n-\mathrm{C}_{30}-2,29$-diol & 1 & 1 & 0 & 1 \\
\hline Hop-22(29)-ene & 4 & 2 & 3 & 0 \\
\hline
\end{tabular}

${ }^{\star}$ Containing 9 or 10 double bonds.

(Fig. 2). The three novel strains possessed nearly identical (99.8-99.9\% similarity) 16S rRNA gene sequences. The closest phylogenetic relatives $(97.5-97.8 \%$ sequence similarity) were two strains of taxonomically uncharacterized planctomycetes, Planctomyces sp. strains Schlesner 638 and 642, which were isolated from a compost leakage water (Ward et al., 1995). The closest taxonomically described organism was $P$. limnophilus DSM $3776^{\mathrm{T}}$ (86.9-87.1\% sequence similarity). The level of $16 \mathrm{~S}$ rRNA gene similarity between the novel isolates and the other cultured species of the genus Planctomyces, Planctomyces maris and $P$. brasiliensis, was $83.6-85.6 \%$.

The DNA G $+\mathrm{C}$ content of the novel strains ranged from 54.4 to $56.5 \mathrm{~mol} \%$. The corresponding value reported for
P. limnophilus was 53.2-54.4 mol\% (Hirsch \& Müller, 1985). The DNA-DNA hybridization value of strain MPL7 $^{\mathrm{T}}$ with $P$. limnophilus DSM $3776^{\mathrm{T}}$ was $28 \%$. This low level of genomic DNA relatedness suggests the differentiation of the novel strains at the genus level, which is also supported by the results of fatty acid analysis and a number of physiological tests.

We therefore propose that strains MPL7 ${ }^{\mathrm{T}}$, MOB77 and SB2 should be classified as representatives of a novel genus and species, for which the name Schlesneria paludicola gen. nov., sp. nov. is proposed. Compared with representative of the genus Planctomyces members of this novel taxon have greater tolerance of acidic conditions and low temperatures, are more sensitive to $\mathrm{NaCl}$, lack pigmentation and degrade a wider range of biopolymers (Table 4).

\section{Description of Schlesneria gen. nov.}

Schlesneria (Schles.ne'ri.a. N.L. fem. n. Schlesneria named in honour of the German microbiologist Heinz Schlesner, for his outstanding contribution to increasing our knowledge on planctomycete diversity and ecology).

Ellipsoid-like cells that occur singly or in pairs or are arranged in rosettes. Encapsulated. Reproduce by budding. Buds arise from the free cell pole of the mother cells. Adult cells are immobile. Daughter cells are motile by means of two subpolar flagella. Cells are connected to each other by means of numerous fibrillar appendages. Stalk-like structures are short and rarely observed. Colonies are small and uncoloured. Chemo-organotrophic facultative aerobes. Possess weak hydrolytic capabilities. Catalase- and cytochrome oxidase-positive, but urease-negative. Dissimilatory nitrate reduction is positive. Moderately acidophilic and mesophilic. Sensitive to $\mathrm{NaCl}$. The major quinone is

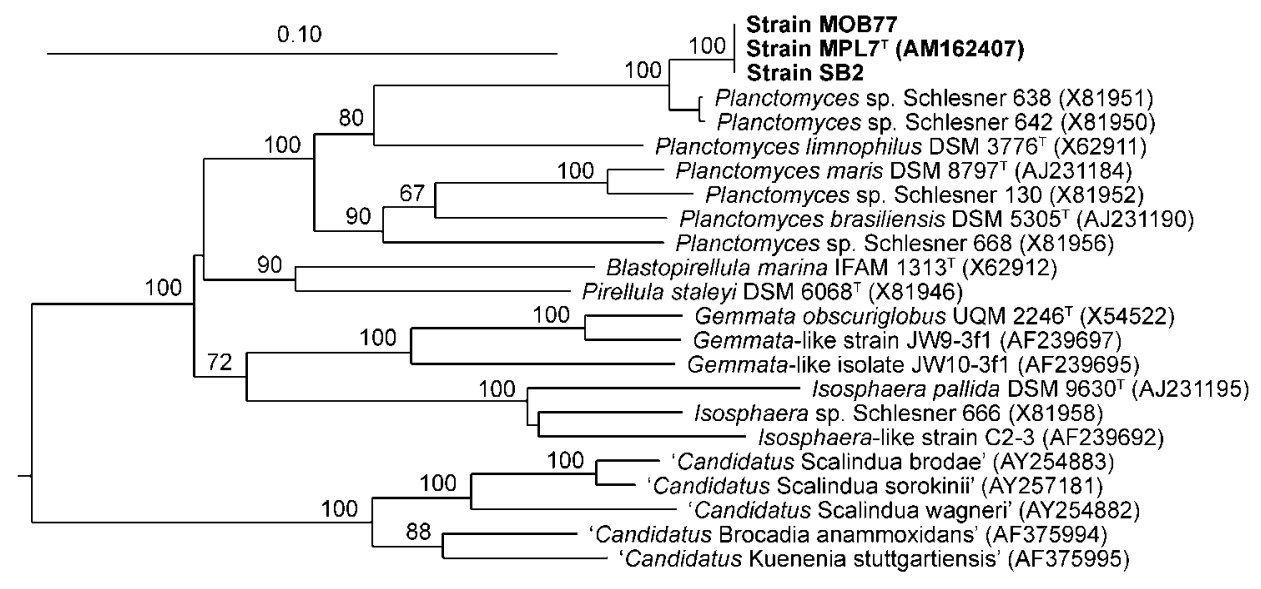

Fig. 2. $16 \mathrm{~S}$ rRNA gene sequence-based neighbour-joining tree showing the phylogenetic position of strains $M P L 7^{\top}, \mathrm{SB}^{2}$ and MOB77 in relation to members of the genus Planctomyces and some other representatives of the phylum 'Planctomycetes'. Bootstrap values (percentages of 1000 data resamplings) $>50 \%$ are shown. The 16S rRNA gene sequence of Chlorobium limicola UdG 6040 (GenBank accession no. Y10642) was used as an outgroup (not shown). Bar, 0.1 substitutions per nucleotide position. 
Table 4. Major characteristics that distinguish Schlesneria gen. nov. from the genus Planctomyces

\begin{tabular}{|c|c|c|}
\hline Characteristic & Schlesneria & Planctomyces \\
\hline Colony pigmentation & Unpigmented & $\begin{array}{c}\text { Pink to red (P. limnophilus), yellow } \\
\text { (P. brasiliensis) or colourless to light rose } \\
(\text { P. maris })\end{array}$ \\
\hline Cell shape & Ellipsoid & Ovoid to spherical \\
\hline Stalks & Short and rarely observed & Very common \\
\hline Presence of a capsule & + & - \\
\hline Growth at pH 5 & + & - \\
\hline Growth at $\mathrm{pH} 8$ & - & + \\
\hline Growth at $4{ }^{\circ} \mathrm{C}$ & + & - \\
\hline Growth at $35{ }^{\circ} \mathrm{C}$ & - & + \\
\hline Tolerance of $>0.5 \% \mathrm{NaCl}$ & - & + \\
\hline Major PLFAs & $\mathrm{C}_{16: 0}, \mathrm{C}_{16: 1} \omega 7 c$ & $\mathrm{C}_{16: 0}, \mathrm{C}_{18: 1} \omega 9 c, \mathrm{C}_{16: 1} \omega 7 c$ \\
\hline DNA G $+\mathrm{C}$ content $(\mathrm{mol} \%)$ & $54-57$ & $51-58$ \\
\hline
\end{tabular}

MK-6. The major fatty acids are $\mathrm{C}_{16: 0}$ and $\mathrm{C}_{16: 1} \omega 7 c$; the major neutral lipids are $n-\mathrm{C}_{31}$ polyunsaturated alkenes, $n$ - $\mathrm{C}_{26}-2,25$-diols and $n$ - $\mathrm{C}_{24}-2,23$-diols. The genus is a member of the phylum 'Planctomycetes', order Planctomycetales, family Planctomycetaceae. The type species is Schlesneria paludicola.

\section{Description of Schlesneria paludicola sp. nov.}

Schlesneria paludicola (pa.lu.di'co.la. L. n. palus -udis a marsh, bog; L. suff. -cola inhabitant, dweller; N.L. n. paludicola a bog-dweller).

Displays the properties given in the genus description. Mature cells are 1.3-2.1 $\mu \mathrm{m}$ long and $0.6-1.5 \mu \mathrm{m}$ wide. Free cell poles are covered with crateriform pits and possess an unusual spur-like projection, which gives rise to a cell shape with some similarity to a lemon. Carbon sources $(0.05 \%$, w/v) include glucose, $N$-acetylglucosamine, cellobiose, maltose, sucrose, trehalose, fucose and salicin. Cannot utilize fructose, galactose, raffinose, rhamnose, sorbose, ribose, glycerol, methanol, ethanol, glucuronic acid, acetate, benzoate, caproate, citrate, fumarate, glutarate, lactate, malate, pyruvate, succinate, propionate, mannitol, tartrate, alanine, arginine, asparagine, aspartate, cysteine, cystine, glutamine, glycine, histidine, isoleucine, leucine, lysine, methionine, norleucine, ornithine, phenylalanine, proline, serine, threonine, tryptophan, tyrosine or valine. Capable of hydrolysing fucoidan, laminarin, aesculin, pectin, chondroitin sulfate, pullulan, gelatin and xylan. Cannot hydrolyse starch, lichenan or chitin. Nitrogen sources $(0.05 \%, \mathrm{w} / \mathrm{v})$ include ammonia, nitrate, $N$ acetylglucosamine, Bacto peptone, Bacto yeast extract, alanine, aspartate, glutamine and threonine. Vitamins are not required. Resistant to ampicillin, streptomycin, chloramphenicol, lincomycin and novobiocin, but sensitive to neomycin, kanamycin and gentamicin. Capable of growth at $\mathrm{pH} 4.2-7.5$ (optimum $\mathrm{pH} 5.0-6.2$ ) and at $4-32{ }^{\circ} \mathrm{C}$ (optimum $15-26^{\circ} \mathrm{C}$ ). $\mathrm{NaCl}$ inhibits growth at concentrations above $0.5 \%(\mathrm{w} / \mathrm{v})$. The $\mathrm{G}+\mathrm{C}$ content of the DNA varies between 54.4 and $56.5 \mathrm{~mol} \%$ (56.3 mol\% for the type strain). Acidic wetlands are the only known habitat.

The type strain is strain MPL7 ${ }^{\mathrm{T}}$ (=VKM B- $2452^{\mathrm{T}}=\mathrm{ATCC}$ BAA-1393 ${ }^{\mathrm{T}}$ ), which was isolated from the Sphagnum peat bog Bakchar, Tomsk region, western Siberia.

\section{Acknowledgements}

This research was supported by the Russian Fund of Basic Research (grant no. 06-04-49148), the Program 'Molecular and Cell Biology' of the Russian Academy of Sciences and the Russian Science Support Foundation. The authors thank A. M. Lysenko for DNA-DNA hybridization analysis and Kees Hordijk for technical assistance in PLFA analyses.

\section{References}

Boschker, H. T. S., Nold, S. C., Wellsbury, P., Bos, D., de Graaf, W., Pel, R., Parkes, R. J. \& Cappenberg, T. E. (1998). Direct linking of microbial populations to specific biogeochemical processes by ${ }^{13} \mathrm{C}$ labelling of biomarkers. Nature 392, 801-805.

Boschker, H. T. S., de Graaf, W., Koster, M., Meyer-Reil, L. A. \& Cappenberg, T. E. (2001). Bacterial populations and processes involved in acetate and propionate consumption in anoxic brackish sediment. FEMS Microbiol Ecol 35, 97-103.

Collins, M. D. (1985). Analysis of isoprenoid quinones. Methods Microbiol 18, 329-366.

De Ley, J., Cattoir, H. \& Reynaerts, A. (1970). The quantitative measurement of DNA hybridization from renaturation rates. Eur $J$ Biochem 12, 133-142.

Dedysh, S. N., Pankratov, T. A., Belova, S. E., Kulichevskaya, I. S. \& Liesack, W. (2006). Phylogenetic analysis and in situ identification of bacteria community composition in an acidic Sphagnum peat bog. Appl Environ Microbiol 72, 2110-2117.

Fuerst, J. A. (1995). The planctomycetes: emerging models for microbial ecology, evolution and cell biology. Microbiology 141, 1493-1506.

Fuerst, J. A. (2004). Planctomycetes - a phylum of emerging interest for microbial evolution and ecology. WFCC Newsl 38, 1-11. http:// www.wfcc.info/NEWSLETTER/newsletter38/ 
Fuerst, J. A. (2005). Intracellular compartmentation in planctomycetes. Annu Rev Microbiol 59, 299-328.

Fuerst, J. A., Gwilliam, H. G., Lindsay, M., Lichanska, A., Belcher, C., Vickers, J. E. \& Hugenholtz, P. (1997). Isolation and molecular identification of planctomycete bacteria from postlarvae of the giant tiger prawn, Penaeus monodon. Appl Environ Microbiol 63, 254-262.

Gerhardt, P., Murray, R. G. E., Costilow, R. N., Nester, E. W., Wood, W. A., Krieg, N. R. \& Phillips, G. B. (editors) (1981). Manual of Methods for General Bacteriology. Washington, DC: American Society for Microbiology.

Giovannoni, S. J., Schabtach, E. \& Castenholz, R. W. (1987). Isosphaera pallida, gen. nov., and comb. nov., a gliding, budding eubacterium from hot springs. Arch Microbiol 147, 276-284.

Hirsch, P. \& Müller, M. (1985). Planctomyces limnophilus sp. nov., a stalked and budding bacterium from freshwater. Syst Appl Microbiol 6, 276-280.

Ivanova, A. O. \& Dedysh, S. N. (2006). High abundance of Planctomycetes in anoxic layers of a Sphagnum peat bog. Microbiology (English translation of Mikrobiologiia) 75, 716-719.

Kerger, B. D., Mancuso, C. A., Nichols, P. D., White, D. C., Langworthy, T., Sittig, M., Schlesner, H. \& Hirsch, P. (1988). The budding bacteria, Pirellula and Planctomyces, with atypical $16 \mathrm{~S}$ rRNA and absence of peptidoglycan, show eubacterial phospholipids and uniquely high proportions of long chain beta-hydroxy fatty acids in the lipopolysaccharide lipid A. Arch Microbiol 149, 255-260.

König, H., Schlesner, H. \& Hirsch, P. (1984). Cell wall studies on budding bacteria of the Planctomyces/Pasteuria group and on Prosthecomicrobium sp. Arch Microbiol 138, 200-205.

Kulichevskaya, I. S., Pankratov, T. A. \& Dedysh, S. N. (2006). Detection of representatives of the Planctomycetes in Sphagnum peat bogs by molecular and cultivation approaches. Microbiology (English translation of Mikrobiologiia) 75, 329-335.

Lindsay, M. R., Webb, R. I., Strous, M., Jetten, M. S., Butler, M. K., Forde, R. J. \& Fuerst, J. A. (2001). Cell compartmentalisation in planctomycetes: novel types of structural organisation for the bacterial cell. Arch Microbiol 175, 413-429.

Ludwig, W., Strunk, O., Westram, R., Richter, L., Meier, H., Yadhukumar, Buchner, A., Lai, T., Steppi, S. \& other authors (2004). ARB: a software environment for sequence data. Nucleic Acids Res 32, 1363-1371.

Marmur, J. (1961). A procedure for the isolation of deoxyribonucleic acid from microorganisms. J Mol Biol 3, 208-218.

Nichols, P. D., Guckert, J. B. \& White, D. C. (1986). Determination of monounsaturated fatty acid double-bond position and geometry for microbial monocultures and complex consortia by capillary GC-MS of their dimethyl disulphide adducts. J Microbiol Methods 5, 49-55.

Nichols, D. S., Nichols, P. D. \& McMeekin, T. A. (1995). A new n$\mathrm{C}_{31: 9}$ polyene hydrocarbon from Antarctic bacteria. FEMS Microbiol Lett 125, 281-285.

Owen, R. J., Lapage, S. P. \& Hill, L. R. (1969). Determination of base composition from melting profiles in dilute buffers. Biopolymers 7 , 503-516.

Reynolds, E. S. (1963). The use of lead citrate at high $\mathrm{pH}$ as an electron-opaque stain in electron microscopy. J Cell Biol 17, 208-212.

Schlesner, H. (1994). The development of media suitable for the microorganisms morphologically resembling Planctomyces spp., Pirellula spp., and other Planctomycetales from various aquatic habitats using dilute media. Syst Appl Microbiol 17, 135-145.

Schlesner, H. \& Stackebrandt, E. (1986). Assignment of the genera Planctomyces and Pirella to a new family Planctomycetaceae fam. nov. and description of the order Planctomycetales ord. nov. Syst Appl Microbiol 8, 174-176.

Sinninghe Damsté, J. S., Rijpstra, W. I. C., Schouten, S., Fuerst, J. A., Jetten, M. S. M. \& Strous, M. (2004). The occurrence of hopanoids in planctomycetes: implications for the sedimentary biomarker record. Org Geochem 35, 561-566.

Sittig, M. \& Schlesner, H. (1993). Chemotaxonomic investigation of various prosthecate and/or budding bacteria. Syst Appl Microbiol 16, 92-103.

Staley, J. T., Fuerst, J. A., Giovannoni, S. \& Schlesner, H. (1992). The order Planctomycetales and the genera Planctomyces, Pirellula, Gemmata and Isosphaera. In The Prokaryotes: a Handbook on the Biology of Bacteria. Ecophysiology, Isolation, Identification, Applications, 2nd edn, pp. 3710-3731. Edited by A. Balows, H. Trüper, M. Dworkin, W. Harder \& K. H. Schleifer. New York: Springer.

Ward, N., Rainey, F. A., Stackebrandt, E. \& Schlesner, H. (1995). Unraveling the extent of diversity within the order Planctomycetales. Appl Environ Microbiol 61, 2270-2275.

Ward, N., Staley, J. T., Fuerst, J. A., Giovannoni, S., Schlesner, H. \& Stackebrandt, E. (2006). The order Planctomycetales, including the genera Planctomyces, Pirellula, Gemmata and Isosphaera and the Candidatus genera Brocadia, Kuenenia and Scalindua. In The Prokaryotes: a Handbook on the Biology of Bacteria, 3rd edn, vol. 7, pp. 757-793. Edited by M. Dworkin, S. Falkow, E. Rosenberg, K. H. Schleifer \& E. Stackebrandt. New York: Springer.

Weisburg, W. G., Barns, S. M., Pelletier, D. A. \& Lane, D. J. (1991). 16 S ribosomal DNA amplification for phylogenetic study. J Bacteriol 173, 697-703. 